\title{
PERSONAL INFORMATION MANAGEMENT DAN PERILAKU MAHASISWA UNIVERSITAS DIPONEGORO DALAM MEMANFAATKAN BOOKMARK MANAGER
}

\author{
Mutia Larasati \\ Universitas Diponegoro \\ Email : mutialr22@gmail.com \\ Yanuar Yoga Prasetyawan \\ Universitas Diponegoro \\ Email : yanuaryoga@live.undip.ac.id
}

\begin{abstract}
Personal information management activities represent the activities of an individual in storing, as well as recovering the information in his possession. This activity aims to make it easier for someone to organize their information effectively and efficiently. The error encountered by researchers is that students only store the information they have obtained into the bookmark manager without organizing the information. The storage period for information that has been stored is approximately 3-4 years and the rest of the information is no longer useful. The purpose of this study was to identify the personal information management and behavior of Undip students in utilizing bookmark managers. The method used in this research is qualitative. The data collection technique of this research used observation and semi-structured interviews. Informants were selected using a purposive sampling technique. 6 informants have been interviewed. The data analysis technique used was qualitative data analysis from Miles and Huberman which consisted of data reduction, data display, and conclusion drawing. The results showed that the information management activities carried out by students included: selecting, storing, and managing student information. Also, bookmark managers have a positive impact on students, because they are effective and efficient enough to be used continuously. Furthermore, the final activity is to evaluate by identifying the information held by sorting or deleting the information stored in the bookmark manager.
\end{abstract}

Keywords: personal information management, Information behavior, bookmark manager, students

\begin{abstract}
Abstrak : Kegiatan manajemen informasi pribadi merupakan serangkaian kegiatan seorang individu dalam menyimpan, mengelola, maupun menemukan kembali informasi yang dimilikinya. Kegiatan ini bertujuan untuk mempermudah seseorang dalam mengorganisir informasi yang milikinya dengan efektif dan efisien. Permasalahan yang ditemui oleh peneliti yaitu mahasiswa hanya menyimpan informasi yang telah diperolehnya ke dalam bookmark manager tanpa melakukan pengorganisasian informasi. Jangka waktu penyimpanan informasi yang telah disimpan kurang lebih 3-4 tahun dan selebihnya informasi tersebut sudah tidak berguna lagi. Tujuan dari penelitian ini untuk mengidentifikasi
\end{abstract}


Mutia Larasati, Yanuar Yoga Prasetyawan, Personal Information ...

manajemen informasi pribadi dan perilaku mahasiswa Undip dalam memanfaatkan bookmark manager. Metode yang digunakan dalam penelitian ini ialah metode kualitatif. Teknik pengambilan data penelitian ini menggunakan observasi dan wawancara semi terstruktur. Informan dipilih dengan menggunakan teknik purposive sampling. Terdapat 6 informan yang telah diwawancari. Teknik analisis data yang digunakan yaitu analisis data kualitatif dari Miles dan Huberman yang terdiri dari reduksi data, display data, dan penarikan kesimpulan. Hasil penelitian menunjukkan bahwa kegiatan manajemen informasi yang dilakukan oleh mahasiswa meliputi: penyeleksian, penyimpanan dan pengelolaan informasi mahasiswa. Selain itu bookmark manager memberikan dampak positif bagi mahasiswa, karena cukup efektif dan efisien untuk digunakan secara terusmenerus. Selanjutnya kegiatan akhir yaitu melakukan evaluasi dengan mengidentifikasi informasi yang dimiliki dengan menyortir maupun menghapus informasi yang tersimpan dalam bookmark manager.

Kata kunci : manajemen informasi pribadi, perilaku informasi, bookmark manager, mahasiswa

\section{PENDAHULUAN}

Dewasa ini, perkembangan teknologi semakin pesat dan arus informasi semakin tidak terkendali. Setiap individu dituntut untuk mampu memenuhi kebutuhan informasinya berdasarkan berbagai sumber informasi yang ada. Informasi yang tersaji dihadapan setiap individu belum tentu merupakan informasi yang berguna dan sesuai dengan kebutuhan. Kebutuhan informasi juga dipengaruhi oleh adanya ketidakseimbangan antara informasi yang dimiliki dengan informasi yang dibutuhkan. Akibatnya setiap individu berusaha untuk memenuhi kebutuhan informasinya dengan melakukan penelusuran informasi.

Kegiatan penelusuran informasi antar individu satu dengan individu lainnya berbeda. Ketika seorang individu melakukan penelusuran informasi guna memenuhi kebutuhan informasi dapat dilihat bagaimana perilaku seorang individu tersebut. Menurut Wilson ${ }^{1}$, perilaku informasi merupakan suatu totalitas dari perilaku manusia dalam hubungannya dengan sumber dan saluran informasi baik pengambilan informasi secara aktif dan pasif maupun dalam penggunaan informasi. Penelusuran informasi dapat dilakukan dengan menggunakan berbagai

\footnotetext{
${ }^{1}$ Donghee Sinn, Sujin Kim, and Sue Yeon Syn, "Information Activities within Information Horizons: A Case for College Students' Personal Information Management," Library and Information Science Research 41, no. 1 (2019): 19-30, https://doi.org/10.1016/j.lisr.2019.02.003.
} 


\section{Pustakaloka: Zurnal Kajian 2nformasi dan Perpustakaan}

Volume 12 No. 2, Desember 2020

macam platform, salah satunya dengan menggunakan mesin pencari google chrome. Penggunaan mesin pencari ini bertujuan untuk membantu seorang individu dalam mengakses informasi yang dibutuhkan. Penelusuran informasi yang dilakukan melalui mesin pencari akan menghasilkan URL (Uniform Resource Locator) atau hyperlink (informasi) yang tertaut dalam situs web berupa angka, huruf, dan simbol untuk memudahkan pengguna menuju alamat yang dicari. Informasi yang muncul pada kolom search engine dapat disimpan oleh seorang individu dengan menggunakan fitur bookmark manager yang telah tersedia pada google chrome.

Bookmark manager merupakan suatu media penyimpanan informasi dari hasil penelusuran informasi berupa alamat link yang diperoleh dari hasil penelusuran. ${ }^{2}$ Fungsi bookmark adalah alat yang memungkinkan pengguna untuk secara sukarela menyimpan dan mengklasifikasikan informasi hasil dari pencarian. Informasi yang telah diperoleh nantinya akan dikelola, disimpan, dan digunakan kembali dalam sebuah folder yang telah tersedia pada bookmark manager. Selain itu, fungsi bookmark yaitu untuk memberi pengguna kemampuan untuk memuat banyak folder dan subfolder untuk menyimpan, mengambil, dan sumber informasi organisasi. Dengan adanya fitur boomark manager dapat digunakan sebagai alat menyimpan hasil pencarian yang telah disimpan dan dikelola untuk nantinya dapat digunakan kembali. Penggunaan folder memberikan kemudahan bagi penggunanya, informasi yang telah diperoleh dapat dikelola ke dalam folder yang tersedia pada fasilitas bookmark manager. ${ }^{3}$

Menurut Whittaker et al., ${ }^{4}$ saat berurusan dengan informasi digital, seorang individu perlu memutuskan apakah akan informasi yang telah ditemukan akan disimpan ke dalam sebuah folder atau sub folder elektronik atau

\footnotetext{
${ }^{2}$ Dan Balanescu, "The Youth of Today - The Generation of the Global Development - Special Section for Students and MA Students A Lead Provided by Bookmarks - Intelligent Browsers," 2015, 720-26.

${ }^{3}$ Siu Tsen Shen, "Exploring the Effects of Multidimensional Context on Human Performance in Personal Bookmark Management," Mathematical Problems in Engineering 2013 (2013), https://doi.org/10.1155/2013/932586.

4 Steve Whittaker et al., "Am I Wasting My Time Organizing Email? A Study of Email Refinding," Conference on Human Factors in Computing Systems - Proceedings, 2011, 3449-58, https://doi.org/10.1145/1978942.1979457.
} 
Mutia Larasati, Yanuar Yoga Prasetyawan, Personal Information ...

menumpuknya di desktop. Penggunaan folder harus dikelola dengan baik agar memberikan manfaat dalam segi efektifitas dan efisiensi. Adanya fasilitas folder memberikan kesempatan bagi seorang individu untuk mengkategorikan informasi sesuai dengan kebutuhannya. ${ }^{5}$ Semakin baik seorang individu dalam mengatur item informasi yang mereka miliki, maka semakin mudah bagi mereka untuk menemukan dan mengambilnya kembali. Berbagai informasi yang telah diperoleh dari hasil penelusuran informasi dapat disimpan, dikelola, serta digunakan kembali sesuai dengan kebutuhannya.

Kegiatan tersebut termasuk dalam personal information management (PIM). Menurut Jones, ${ }^{6}$ PIM merupakan praktik dan studi yang membahas mengenai aktivitas yang dilakukan individu untuk memperoleh, mengelola, mengambil, menggunakan dan mengontrol distibusi informasi seperti halnya dokumen (tercetak dan digital) halaman web dan pesan email untuk kegiatan sehari-hari guna menyelesaikan tugas dan memenuhi berbagai peran dan tanggung jawab. $^{7}$ Seorang individu melakukan manajemen informasi pribadi didasarkan pada kebutuhan informasi yang mengarah pada penemuan informasi yang relevan. Penggunaan bookmark manager dapat membantu seseorang dalam menemukan informasi yang relevan dan telah disimpan sebelumnya (temu balik). Hal ini berdampak pada waktu penelusuran informasi yang singkat, efektif, dan efisien. Setiap individu tidak perlu mengakses informasi dari awal, melainkan dapat langsung menuju ke bookmark manager yang telah digunakan untuk menyimpan dan mengelola informasi yang diperoleh sebelumnya. Informasi yang telah ditemukan dan dikelola dengan baik tentunya akan berdampak pada mudahnya individu dalam menemukan kembali informasi yang telah disimpannya. Manajemen perlu dilakukan untuk membantu meringankan kegiatan sehari-hari

\footnotetext{
5 Ofer Bergman and Steve Whittaker, "The Science of Managing Our Digital Stuff," MIT Pres, 2016, https://doi.org/10.17723/0360-9081-81.1.233

${ }^{6}$ William Jones, "Personal Information Management," Annual Review of Informartion Science \& Technology 41, no. 1 (2007): 453-504, https://doi.org/10.1002/aris.2007.1440410117.

7 Lala Hajibayova, "Exploring Individuals' Patterns of Personal Information Management Practices: Factors Influencing the Representation, Organization and Credibility Assessment of Information," Information Research 24, no. 3 (2019).
} 
seperti halnya melakukan manajemen informasi. ${ }^{8}$ Kegiatan pengorganisasian penting untuk dilakukan seseorang pada ruang pribadi untuk menemukan kembali informasi secara efisien.

Hasil survei oleh Dianna Booher dalam Etzel dan Thomas, ${ }^{9}$ hampir $75 \%$ orang hanya menumpuk informasi pribadi yang dimiliki dan saat akan kembali membutuhkan informasi yang telah disimpan tidak dapat menemukan kembali informasi tersebut. Selain itu, hasil survei dari Dartnell Institute 95\% dari informasi yang dimiliki oleh individu hanya menumpuk dan tidak digunakan lagi dalam jangka waktu lebih dari 3 tahun. Informasi pribadi yang dimiliki individu apabila tidak mempunyai pengaturan baik bukan tidak mungkin informasi telah disimpan hanya akan mendatangkan masalah saja bagi seseorang. Informasi pribadi memberikan penyelesaian tugas dan aktivitas individu didalam kesehariannya. Seorang individu perlu melakukan manajemen informasi pribadi agar informasi yang dimiliki dapat digunakan kembali jika sewaktu-waktu dibutuhkan dan tidak membutuhkan waktu yang lama untuk menemukan kembali.

Berdasarkan hasil observasi awal yang dilakukan pada hari Senin, 2 Maret 2020 peneliti menemukan fakta bahwa mahasiswa hanya menambahkan informasi yang telah diperolehnya ke dalam bookmark manager tanpa melakukan pengorganisasian informasi. Jangka waktu penyimpanan informasi yang dimiliki kurang lebih 3-4 tahun dan selebihnya informasi tersebut sudah tidak berguna lagi. Namun, ditemui juga mahasiswa yang membuat folder khusus untuk menyimpan informasi yang dimiliki. Ketika mahasiswa melakukan penemuan kembali pada informasi yang telah disimpan ke dalam bookmark manager, mahasiswa merasa kesulitan untuk menemukannya. Permasalahan ini disebabkan karena saat melakukan penyimpanan tidak menerapkan manajemen informasi dengan benar. Dengan adanya penelitian ini, mengidentifikasi kegiatan manajemen informasi

${ }^{8}$ Lilach Alon and Rafi Nachmias, "Gaps between Actual and Ideal Personal Information Management Behavior," Computers in Human Behavior 107, no. February (2020): 106292, https://doi.org/10.1016/j.chb.2020.106292.

${ }_{9}$ Barbara and Peter J. Thomas Etzel, Personal Information Management: Tools and Techniques for Achieving Professional Effectiveness (Publication Data, 1996). 


\section{Mutia Larasati, Yanuar Yoga Prasetyawan, Personal Information ...}

pribadi dan perilaku mahasiswa dalam memanfaatkan bookmark manager sebagai media penyimpanan informasi.

Menurut Chaudhry ${ }^{10}$ penting untuk menyelidiki praktik apa yang digunakan saat ini untuk menemukan dan mengelola informasi, dan faktor apa yang mempengaruhi pilihan seorang individu untuk mengadopsi strategi yang berbeda, sebelum menyarankan manajemen informasi khusus perilaku untuk membantu menemukan dan menemukan kembali informasi dengan lebih efektif. PIM menjadi hal penting dikarenakan kian banyaknya informasi yang hilir mudik setiap harinya. Semakin hari semakin banyaknya informasi yang dibutuhkan oleh individu, tak terkecuali mahasiswa.

\section{METODE PENELITIAN}

Penelitian ini menggunakan metode penelitian kualitatif, menurut Moleong, ${ }^{11}$ penelitian kualitatif merupakan penelitian yang memahami fenomena tentang apa yang dialami oleh subjek penelitian, misalnya perilaku, persepsi, motivasi, tindakan, dan lain sebagainya. Penelitian kualitatif bertujuan untuk mengamati dan memahami suatu fenomena yang terjadi secara alamiah dengan mengutamakan proses interaksi komunikasi yang mendalam antara fenomena yang diteliti oleh peneliti. ${ }^{12}$ Oleh sebab itu, peneliti menggunakan metode penelitian kualitatif dalam penelitian terkait personal information management (PIM) dalam memanfaatkan media penyimpanan bookmark manager. Penelitian ini dapat mengamati lebih jauh tentang bagaimana manajemen informasi pribadi dan perilaku mahasiswa dalam mengorganisir informasi yang dimiliki.

Penelitian dengan menggunakan metode kualitatif berhubungan dengan sebuah temuan yang didasarkan oleh data lapangan. Penelitian didasarkan pada kondisi alamiah pada fenomena yang terjadi dan akan menghasilkan penemuan dalam ilmu pengetahuan. Hasil dari penelitian ini untuk mengkaji atau meneliti

\footnotetext{
10 Abdus Sattar Chaudhry, Sajjad ur Rehman, and Lulwah Al-Sughair, "Personal Information Management Practices in the Kuwaiti Corporate Sector," Malaysian Journal of Library and Information Science 20, no. 3 (2015): 27-42.

${ }^{11}$ Lexy J Moleong, Metodologi Penelitian Kualitatif(Jakarta: Remaja Rosdakarya Offset, 2007).

12 Haris Herdiansyah, Metode Penelitian Kualitatif Untuk Ilmu-Ilmu Sosial (Jakarta: Salemba Humanika, 2012).
} 
fenomena yang terjadi pada suatu kondisi alamiah tanpa adanya manipulasi, namun menghasilkan suatu kualitas penelitian yang didasarkan oleh fakta yang ada. Manajemen informasi pribadi dapat dilihat dari bagaimana mahasiswa tersebut dalam melakukan pengorganisasian informasi dan memanfaatkan bookmark manager untuk mendukung kegiatan perkuliahan dan kegiatan seharihari.

Metode pengumpulan data dalam penelitian ini menggunakan wawancara semi-terstruktur. Menurut Sugiyono, ${ }^{13}$ wawancara semi terstruktur bertujuan untuk menemukan permasalahan secara lebih terbuka, dimana pihak yang akan diwawancara diminta pendapat dan ide-idenya. Wawancara dengan bentuk ini lebih terbuka namun harus dibatasi ruang lingkup permasalahan yang sedang diteliti. Terdapat pedoman wawancara yang dijadikan sebagai panduan terkait topik yang akan ditanyakan dan digali. Wawancara semi terstruktur dipilih agar informan tidak merasa terbatasi oleh pertanyaan peneliti. Peneliti mewawancarai secara langsung untuk mengetahui manajemen informasi pribadi dan perilaku mahasiswa Universitas Diponegoro dalam memanfaatkan media penyimpanan bookmark manager.

Teknik yang digunakan untuk menentukan informan yaitu dengan mengggunakan teknik purposive sampling. Teknik pengambilan sampel ini berdasar pada sumber data dengan pertimbangan tertentu, misalnya orang yang dianggap mengetahui tentang kegiatan yang dituju sehingga akan memudahkan peneliti menjelajahi objek atau situasi sosial yang akan diteliti. ${ }^{14}$ Teknik purposive sampling dapat diterapkan pada penelitian ini karena informan yang pilih merupakan seseorang yang memiliki pengetahuan dan pengalaman terkait penggunaan bookmark manager. Dalam menentukan informan, peneliti tidak asal memilih akan tetapi dengan menentukan kriteria yang sudah ditetapkan sebelumnya. Berikut merupakan beberapa kriteria informan:

1. Informan merupakan mahasiswa aktif Universitas Diponegoro.

2. Informan menyimpan hyperlink (informasi) hasil pencarian untuk mendukung

\footnotetext{
${ }^{13}$ Sugiyono, Metode Penelitian Kuantitatif, Kualitatif Dan R\&D (Bandung: PT Alfabet, 2016).

${ }^{14}$ Sugiyono.
} 


\section{Mutia Larasati, Yanuar Yoga Prasetyawan, Personal Information ...}

tugas perkuliahan dan sebagai hiburan.

3. Informan telah menggunakan bookmark manager selama \pm 2 tahun.

4. Informan mampu mengakses kembali hyperlink (informasi) yang telah disimpan di bookmark manager pada browser google chrome.

Berdasarkan kriteria yang sudah ditentukan dengan menggunakan teknik purposive sampling peneliti mendapatkan sebanyak enam mahasiswa untuk dijadikan sebagai informan. Selanjutnya metode analisis data yang digunakan pada penelitian ini yaitu menggunakan teknik analisis data kualitatif dari Miles dan Huberman. ${ }^{15}$ Adapun tahapan yang dilakukan dalam analisis data yang terdiri:

1. Reduksi Data

Suatu data yang diperoleh dalam bentuk laporan atau data yang terperinci yang disusun berdasarkan data yang diperoleh, dimana data tersebut masih perlu dilakukan analisis mendalam. Peneliti memperoleh data hasil wawancara semi terstruktur yang kemudian disusun berdasarkan dari jawaban informan. Data tersebut dilakukan analisis dengan cara menguraikan dan menggabungkan secara runtut hasil wawancara ke dalam sebuah transkrip wawancara. Transkrip tersebut memuat semua hasil wawancara informan yang telah diwawancarai.

2. Display Data

Selanjutnya transkrip wawancara yang telah selesai disusun, dilakukan analisis data. Analisis data dilakukan dengan membuat tabel yang terdiri dari tiga kolom yaitu 1) hasil wawancara, memuat informasi berupa pertanyaan dan jawaban 2) kategori, untuk menentukan tema, dan 3) interpretasi, untuk menentukan makna yang terdapat pada jawaban dari informan. Analisis data ini dilakukan agar hasil wawancara memiliki alur yang jelas.

3. Penarikan Kesimpulan

Penarikan kesimpulan merupakan kegiatan akhir dari penelitian kualitatif. Hasil analisis data yang telah diperoleh dijadikan dasar oleh peneliti untuk menentukan outline (kerangka tulisan) sebagai gagasan atau ide yang

15 Djam'an Satori and Aan Komariah, Metodologi Penelitian Kualitatif (Bandung: Alfabeta, 2012). 
digunakan sebagai rancangan awal dalam menentukan sub bab pembahasan dan hasil dari penelitian.

\section{KAJIAN TEORI}

Personal information management (PIM) merupakan salah satu Menurut Chaudhry kegiatan yang dilakukan dalam mengorganisir informasi pribadi yang dimiliki oleh seorang individu tak terkecuali mahasiswa. Informasi yang telah diperoleh dari berbagai sumber informasi perlu dilakukan pengelolaan berdasarkan urgensi dari informasi agar memudahkan dalam penemuan kembali informasi yang telah tersimpan. Menurut Elsweiler, Baillie dan Ruthven, ${ }^{16}$ pencarian kembali informasi merupakan kunci dari aktivitas PIM dan membahas tentang strategi yang harus dilakukan seoranag individu untuk mengelola informasi yang dimiliki secara efektif.

Aktivitas PIM dilakukan dengan tujuan untuk mempermudah mahasiswa dalam mengorganisir informasi yang dimiliki. Informasi tidak hanya dibiarkan tersimpan di dalam bookmark manager namun juga dilakukan pengorganisasian. Dalam melakukan aktivitas PIM dapat dilihat bagaimana perilaku mahasiswa dalam mengorganisir informasinya. Perilaku mahasiswa dapat berpengaruh pada efektivitas maupun efisiensi dari sebuah informasi yang disimpan. Hal ini dapat dilihat dari tiga kegiatan PIM yang terdiri: ${ }^{17}$

\section{Finding}

Kegiatan penemuan informasi guna memenuhi kebutuhan informasi, dimana untuk menemukannya seseorang perlu melakukan akses informasi. Penemuan informasi ini dilakukan dengan mengakses informasi dengan browsing dan melakukan penemuan dengan membaca cepat pada sebuah katalog atau referensi untuk mengenali informasi sesuai dengan kebutuhannya.

\footnotetext{
16 David Elsweiler, Mark Baillie, and Ian Ruthven, "What Makes Re-Finding Information Difficult? A Study of Email Re-Finding," in Lecture Notes in Computer Science (Including Subseries Lecture Notes in Artificial Intelligence and Lecture Notes in Bioinformatics), vol. 6611 LNCS (Berlin, Germany: Spring-Verlag, 2011), 568-79, https://doi.org/10.1007/978-3-64220161-5_57.

17 William Jones, Keeping Found Things Found: The Study of Practice Personal Information Management (Morgan Kaufmann Publishers, 2008).
} 
Mutia Larasati, Yanuar Yoga Prasetyawan, Personal Information ...

Maka dari itu, penemuan informasi dapat dilaksanakan pada dua ruang yaitu penemuan informasi pada ruang informasi yang pernah ditemukan (re-finding) dan pada ruang informasi yang baru (new-finding). Re-finding merupakan penemuan informasi pada sebuah ruang informasi yang pernah dikunjungi. Sedangkan new-finding merupakan kegiatan penemuan informasi yang belum pernah ditemukan sebelumnya.

2. Keeping and Organizing

Keeping dan organizing merupakan dua istilah yang berbeda namun berkaitan. Keeping artinya menyimpan informasi pada sebuah media penyimpanan, sedangkan organizing artinya mengatur letak informasi yang akan disimpan dengan memberikan nama pada informasi tersebut.

Terdapat dua bentuk model penyimpanan dalam PIM yaitu filing dan piling. Filing merupakan model penyimpanan yang dilakukan oleh individu dengan cara menyeleksi informasi yang diperoleh, kemudian menyimpan informasi tersebut kedalam sebuah folder dan memberikan nama. Sedangkan, piling yaitu model penyimpanan informasi yang dilakukan individu tanpa adanya proses seleksi dan tidak memberikan nama pada folder yang akan disimpan, dengan kata lain informasi yang didapatkan dari berbagai sumber hanya ditumpuk begitu saja. ${ }^{18}$

3. Meta-level

Dalam kegiatan meta-level terdiri dari pemeliharan informasi (maintaining) yaitu pemeliharaan dilakukan dengan alasan bahwa informasi merupakan aset yang berharga, informasi yang sangat sulit untuk digantikan, koleksi referensi, dan informasi pekerjaan. Selanjutnya yaitu pengelolaan arus informasi dengan tujuan untuk menghemat waktu dan keuangan, fokus pada kebutuhan, serta diri sendiri. Kemudian terdapat measuring dan evaluating, kedua hal ini membantu seseorang dalam mengambil keputusan dalam hal efektifitas, efisiensi, dan kepuasan. Terakhir yaitu sense making yang

\footnotetext{
${ }^{18}$ Thomas W. Malone, "How Do People Organize Their Desks?: Implications for the Design of Office Information Systems," ACM Transactions on Information Systems (TOIS) 1, no. 1 (1983): 99-112, https://doi.org/10.1145/357423.357430.
} 
diibaratkan sebagai gap atau kesenjangan yang berupa pertanyaan dan kebingungan terhadap suatu informasi.

\section{HASIL PENELITIAN DAN PEMBAHASAN}

Manajemen informasi pribadi tidak hanya mengungkap tentang bagaimana seorang individu dalam mengelola informasi, namun juga dapat memberikan perencanaan kegiatan yang dapat berguna dimasa yang akan datang. Tujuan dari penelitian ini untuk mengidentifikasi bagaimana manajemen informasi pribadi dan perilaku mahasiswa Universitas Diponegoro (Undip) dalam memanfaatkan bookmark manager sebagai media penyimpanan informasi dalam mendukung kegiatan sehari-hari. Bookmark manager menjadi sebuah media penyimpanan utama dalam menyimpan informasi berupa alamat link atau URL yang disimpan untuk memenuhi kebutuhan informasi khususnya mahasiswa. Fokus penelitian ini didasarkan pada serangkaian kegiatan manajemen informasi pribadi dan perilaku mahasiswa dalam menggunakan bookmark manager sebagai media penyimpanan.

\section{Manajemen Informasi Pribadi dan Perilaku Mahasiswa Undip dalam Memanfaatkan Bookmark Manager}

Manajemen informasi pribadi dan perilaku mahasiswa merupakan dua hal yang berbeda, namun ketika seorang mahasiswa melakukan manajemen informasi dapat dilihat perilaku yang muncul. Manajemen yang dimaksud seperti halnya kegiatan yang berupa perencanaan, pengorganisasian, pengarahan, maupun evaluasi. Kegiatan manajemen terintegrasi dengan informasi yang dimiliki oleh mahasiswa, informasi ini sebelumnya sudah ditemukan, disimpan dan bisa diakses kembali pada bookmark manager. Jika mahasiswa melakukan manajemen informasi secara baik, maka membantu mempermudah mahasiswa dalam temu kembali informasi. Oleh sebab itu informasi yang tersimpan dalam bookmark manager tidak boleh asal, melainkan harus melalui proses seleksi terlebih dahulu. Caranya dengan melihat sumber informasi yang didapat apakah sesuai dengan kebutuhan informasi dan dapat dipertanggungjawabkan. Seperti halnya 


\section{Mutia Larasati, Yanuar Yoga Prasetyawan, Personal Information ...}

memperoleh informasi yang berasal dari sumber-sumber informasi terpercaya. Kegiatan ini dilakukan oleh mahasiswa Undip dalam memenuhi kebutuhan informasinya dengan cara melihat sumber informasi yang sesuai.

Informasi yang tersimpan dapat dikategorikan penting maupun tidak berdasarkan kebutuhan dari mahasiswa. Kebutuhan informasi antara mahasiswa satu dengan yang lain berbeda, seperti informasi untuk perkuliahan, hiburan maupun artikel bacaan. Berbagai macam kebutuhan informasi yang berbeda tersebut bisa dikategorikan dalam informasi penting. Perbedaan atau kesenjangan kebutuhan informasi mahasiswa dapat didasarkan pada perilaku seorang individu dalam mengelola informasi yang dimilikinya. Perilaku dalam mengelola informasi dilihat ketika mahasiswa memilah dan memilih informasi mana yang layak untuk disimpan ke dalam bookmark manager. Berdasarkan penelitian sebelumnya diungkapkan adanya kesenjangan antara perilaku aktual dan ideal dikaitkan dengan perasaan negatif individu dan ketidakmampuan individu dalam mengelola informasi pribadi secara efisien. Adanya perbedaan individu antara perilaku PIM aktual dan ideal menunjukkan bahwa dalam sebuah literatur peserta tidak dapat diukur secara eksplisit ataupun empiris. ${ }^{19}$

Melihat pentingnya informasi yang dibutuhkan mahasiswa, manajemen informasi pribadi perlu diterapkan. Hasil penelitian tentang manajemen informasi pribadi dan perilaku mahasiswa dalam menggunakan bookmark manager ini sejalan dengan tujuan penelitian. Tujuan penelitian ini untuk mengidentifikasi manajemen informasi pribadi dan perilaku mahasiswa dalam menggunakan bookmark manager yang dapat dilihat dari kebutuhan informasi dari masingmasing mahasiswa.

Selanjutnya untuk mengantisipasi jika sewaktu-waktu membutuhkan informasi dalam bookmark manager, mahasiswa dapat menemukannya dengan mudah, cepat dan efisien. Bookmark manager menjadi salah satu pilihan di kalangan mahasiswa dalam menyimpan informasinya. Bookmark manager dianggap media yang cukup efektif digunakan untuk mendukung kegiatan

\footnotetext{
19 Alon and Nachmias, "Gaps between Actual and Ideal Personal Information Management Behavior."
} 
keseharian mahasiswa. Penggunaan bookmark manager memudahkan mahasiswa untuk menyimpan informasi, mahasiswa tidak perlu melakukan copy paste alamat link dan menyimpanannya ke tempat lain. Fasilitas yang dimiliki oleh google cukup membantu mahasiswa, salah satunya karena informasi yang disimpan akan bertahan lama selama mahasiswa tersebut mempunyai akun google. Informasi yang telah tersimpan ke dalam bookmark manager, kemudian dapat dilakukan manajemen informasi sesuai dengan kegiatan manajemen pada umumnya.

\section{Manajemen Informasi Pribadi dan Perilaku Mahasiswa dalam Penyeleksian Informasi}

Informasi yang berada disekeliling kita hampir sulit untuk dikendalikan, tanpa mencari informasi terkadang informasi datang dengan sendirinya. Melihat begitu mudahnya informasi menghampiri kita, maka perlu adanya penyeleksian informasi berdasarkan kebutuhan informasi. Penyeleksian yang dimaksud yaitu menyortir informasi berdasarkan isi informasinya. Informasi yang diperoleh tidak serta merta dapat disimpan ke dalam bookmark manager. Melalui penyeleksian informasi peneliti dapat mengetahui manajemen informasi pribadi dan perilaku mahasiswa Undip dalam meyimpan informasi apakah informasi tersebut masih relevan untuk digunakan kembali. Salah satu caranya dengan mengklusterkan informasi ke dalam sebuah folder. Sebagian dari mahasiswa tersebut memanfaatkan fasilitas folder yang telah tersedia pada bookmark manager. Dengan adanya penyeleksian ini dapat dikaitkan dengan tujuan dari penelitian yaitu untuk mengidentifikasi manajemen informasi pribadi dan perilaku informasi mahasiswa dalam menggunakan bookmark manager yang dapat dilihat dari penggunaan folder untuk mengklusterkan informasi.

Terdapat faktor yang mempengaruhi apakah informasi yang diperoleh layak digunakan atau tidak. Salah satunya yaitu dengan mencari isi informasi yang berhubungan dengan perkuliahan maupun kebutuhan informasi yang lainnya. Selain itu ketika telah mendapatkan informasi, mahasiswa meninjau kembali urgensi dari informasi, sudahkan informasi tersebut sesuai dengan dengan kebutuhan dan dapat digunakan kembali. Informasi akan dianggap penting jika 


\section{Mutia Larasati, Yanuar Yoga Prasetyawan, Personal Information ...}

informasi yang tersimpan mengandung informasi yang dapat digunakan untuk memenuhi kebutuhan informasi saat itu juga ataupun dimasa yang akan datang. Hal tersebut menunjukkan bahwa ketika menyimpan informasi mahasiswa melihat urgensi dari informasi yang diperoleh. Jika informasi tersebut memang sesuai dengan kebutuhan maka akan disimpan dengan menggunakan media penyimpanan yaitu bookmark manager. Selain itu mahasiswa juga melihat apakah informasi tersebut kedepannya akan dibutuhkan atau tidak. Penyeleksian juga dapat dilakukan dengan menyortir kembali informasi yang sebelumnya sudah tersimpan. Hal ini dilakukan agar informasi yang tersimpan terkelola dengan baik. Tujuannya yaitu agar informasi yang masih relevan dapat digunakan kembali sebagai bahan referensi maupun bahan bacaan.

Perilaku mahasiswa dalam menyimpan informasi cukup berbeda-beda. Informasi yang disimpan oleh mahasiswa akan diakses kembali dan perlu disortir kembali agar tidak menumpuk dan menyulitkan dalam temu kembali informasi. Informasi yang telah diperoleh mahasiswa akan diakses kembali jika memang mahasiswa tersebut membutuhkannya. Selain itu, informasi yang telah disimpan akan disortir oleh mahasiswa untuk memisahkan informasi yang masih dapat digunakan dengan informasi yang sudah tidak digunakan kembali. Jika informasi sudah tidak digunakan maka informasi tersebut akan dihapus oleh mahasiswa. Hal ini dilakukan untuk menghindari overload dan mempermudah temu kembali informasi pada bookmark manager. Namun ditemukan pula mahasiswa yang tidak mengakses kembali informasi serta tidak menyortir informasi yang disimpan dalam bookmark manager. Berdasarkan hasil penelitian dapat diketahui bahwa sebagian mahasiswa mengakses kembali informasi yang telah disimpannya serta menyortir informasi yang dirasa sudah tidak digunakan kembali. Sedangkan sebagian mahasiswa yang lain tidak mengakses informasinya dan membiarkan informasi yang dimiliki menumpuk dalam bookmark manager. Dengan adanya hal ini untuk melakukan penyeleksian informasi, juga perlu dilihat dari bagaimana seorang mahasiswa melakukan penyimpanan dan pengelolaan informasi yang dimiliki. 


\section{Manajemen Informasi Pribadi dan Perilaku Mahasiswa dalam Penyimpanan dan Pengelolaan Informasi}

Setelah melakukan berbagai proses untuk menentukan apakah informasi tersebut layak untuk disimpan maka yang perlu dilakukan selanjutnya yaitu melakukan pengelolaan informasi. Dalam kegiatan pengelolaan informasi ini terdapat kegiatan penyimpanan informasi dalam memanfaatkan bookmark manager. Manajemen informasi pribadi terdapat kegiatan keeping dan organizing. Keeping dan organizing merupakan dua istilah yang berbeda namun saling berkaitan. Keeping dapat diartikan menyimpan informasi pada media penyimpanan dalam hal ini yaitu bookmark manager. Sedangkan organizing merupakan mengatur letak informasi yang akan disimpan dengan memberikan nama pada informasi tersebut. ${ }^{20}$

Sedangkan model penyimpanan informasi dalam PIM terbagi menjadi dua yaitu filing dan piling. Filing merupakan model penyimpanan dengan melakukan proses seleksi pada informasi Menurut Jones yang diperoleh, kemudian menyimpan informasi tersebut kedalam folder dan memberikan nama. Sedangkan, piling yaitu model penyimpanan informasi yang dilakukan individu tanpa adanya proses seleksi dan tidak memberikan nama pada folder yang akan disimpan. Dengan kata lain informasi yang didapatkan dari berbagai sumber hanya ditumpuk begitu saja. ${ }^{21}$

Model penyimpanan informasi antara satu mahasiswa dengan mahasiswa lain cukuplah berbeda ada yang menggunakan model filing dan ada juga yang menggunakan model piling. Model filing ini menjelaskan bahwa mahasiswa dalam melakukan penyimpanan informasi menggunakan folder yang tersedia dalam bookmark manager. Penggunaan folder dirasa memudahkan mahasiswa dalam penyimpanan. Selain itu, mahasiswa juga menggunakan folder ini untuk mengelompokkan folder tersebut ke dalam satu jenis kebutuhan informasi. Folder akan diberi nama sesuai dengan informasi yang disimpan. Mahasiswa merasa terbantu untuk mencari kembali informasi yang sebelumnya telah disimpan dalam

${ }^{20}$ Jones, Keeping Found Things Found: The Study of Practice Personal Information Management. ${ }^{21}$ Malone, "How Do People Organize Their Desks?: Implications for the Design of Office Information Systems." 


\section{Mutia Larasati, Yanuar Yoga Prasetyawan, Personal Information ...}

folder tanpa harus menelusur kembali melalui tahap awal pencarian informasi. Selain itu, dengan adanya bookmark manager ini mahasiswa merasa terbantu untuk memenuhi kebutuhan informasi sehari-hari. Bookmark juga dirasa cukup efektif, mereka hanya perlu membuka kembali pada folder yang sudah mereka buat sebelumnya.

Akan tetapi, didapati pula mahasiswa yang tidak menggunakan folder dalam menyimpan informasinya. Mahasiswa ini menggunakan model piling yaitu menyimpan informasi tanpa melakukan proses seleksi dan memberikan nama pada informasi tersebut. Selama tidak menggunakan folder dalam menyimpan informasi terdapat mahasiswa yang mengalami kendala untuk mengelola informasi. Mahasiswa merasa kesulitan untuk menemukan kembali informasinya yang membuat mahasiswa harus mencari kembali informasinya di dalam bookmark manager yang mereka miliki. Namun dijumpai pula mahasiswa yang tidak menggunakan folder dalam menyimpan informasi tidak mengalami kesulitan dalam menemukan kembali informasinya. Hal ini karena mahasiswa merasa sudah memahami betul informasi yang disimpannya. Berdasarkan hasil penelitian terkait manajemen informasi pribadi dan perilaku mahasiswa dalam menggunakan bookmark manager ini sejalan dengan tujuan penelitian. Dalam praktiknya kegiatan manajemen informasi pribadi dan perilaku mahasiswa dapat diketahui bagaimana pengelolaan dan penyimpanan informasi dari masing-masing mahasiswa.

Berdasarkan hasil penelitian sebelumnya yang dikemukan oleh Chaudry, Rehman, dan Al-Sughai ${ }^{22}$ menunjukkan bahwa pengetahuan pekerja di sektor swasta dalam mengumpulkan informasi sangat bergantung pada sumber-sumber perusahaan, sosial media, dan situs web. Informasi disimpan untuk penggunaan di masa yang akan datang dalam folder elektronik (hardisk), menambahkan favorit dan bookmark di browser internet, dan URL disimpan dari situs dalam catatan pribadi lainnya. Pekerja mengatur informasi dalam folder menggunakan kategori

22 Chaudhry, ur Rehman, and Al-Sughair, "Personal Information Management Practices in the Kuwaiti Corporate Sector." 
yang berhubungan dengan pekerjaan yang berbeda seperti struktur organisasi, format file, dan jenis dokumen.

Informasi yang tersimpan dalam bookmark manager memiliki jangka waktu penyimpanan yang berbeda-beda antar mahasiswa. Informasi yang telah digunakan untuk memenuhi kebutuhan informasi kemungkinan tidak digunakan kembali kedepannya, informasi akan langsung dihapus untuk mempermudah mahasiswa dalam memanfaatkan bookmark manager. Penyimpanan dan pengelolaan informasi yang telah dibahas di atas memberikan gambaran bagaimana manajemen informasi pribadi dan perilaku mahasiswa yang mencakup penyimpanan dan pengelolaan informasi dalam memanfaatkan bookmark manager.

\section{Dampak Manajemen Informasi Pribadi dan Perilaku Mahasiswa dalam Kegiatan Sehari-hari}

Pelaksanaan manajemen informasi pribadi mahasiswa dengan menggunakan bookmark manager untuk mendukung kegiatan sehari-hari memberikan dampak bagi penggunanya dalam hal ini mahasiswa. Bookmark manager diperuntukkan untuk membantu seorang individu khususnya mahasiswa dalam menyimpan, mengelola, maupun menemukan kembali informasi yang dimiliki. Dalam konsep PIM yang dikemukakan oleh Jones pada pembahasan measuring dan evaluating menjelaskan bahwa measuring (pengukuran) merupakan konsep-konsep yang ditetapkan oleh Internasional Organization (ISO dokumen 9241) adalah efektifitas, efisiensi, dan kepuasan. Dengan adanya media penyimpanan ini memberikan dampak yang baik dari segi efisiensi maupun efektifitas. Menurut mahasiswa dengan menggunakan bookmark manager ini pekerjaan lebih efektif dan efisien. Mahasiswa juga merasakan berbagai dampak yang positif, dari segi waktu mempersingkat waktu untuk menemukan kembali informasinya.

Penggunaan bookmark manager cukup praktis untuk diterapkan secara terus-menerus. Dengan menggunakan bookmark manager ini informasi yang telah diperoleh dapat digunakan kembali untuk mengerjakan tugas di waktu yang lain. 


\section{Mutia Larasati, Yanuar Yoga Prasetyawan, Personal Information ...}

Selain memberikan dampak yang positif dari segi efisiensi maupun efektifitas penggunaan bookmark manager juga memberikan banyak manfaat bagi mahasiswa. Hampir seluruh informan dari penelitian ini merasakan manfaat dari penggunaan bookmark manager ini. Manfaat yang dirasakan antar mahasiswa berbeda-beda sesuai dengan kebutuhan mereka. Hal ini dapat dilihat dari fungsi yang bookmark yang membantu pengguna untuk menyimpan tautan atau hyperlink yang didapatkan dari hasil pencarian. Dampak dalam segi efisiensi maupun efektifitas dalam menggunakan bookmark manager ini dapat mengungkapkan tujuan penelitian. Bahwa tujuan dari penelitian ini yaitu untuk mengidentifikasi manajemen informasi pribadi dan perilaku mahasiswa dalam menggunakan bookmark manager.

Berdasarkan hasil penelitian mengungkapkan bahwa praktik PIM menunjukkan bahwa alat yang paling sering digunakan untuk menyimpan informasi yang ditemukan yaitu pada komputer pribadi, dokumen digital, URL, dan hyperlink. URL menjadi elemen yang paling umum digunakan untuk menyimpan informasi online yang digunakan untuk masa depan. Strategi instruksi PIM yang tepat untuk memfasilitasi mahasiswa yang berurusan dengan pertumbuhan jumlah informasi dan mengelola informasi menjadi efektif serta efisien. $^{23}$

Mahasiswa memanfaatkan bookmark manager untuk menyimpan alamat link hasil pencarian untuk mendukung kegiatan perkuliahan. Jika sewaktu-waktu membutuhkan informasi yang telah disimpan mereka hanya perlu membuka kembali pada bookmark manager tanpa harus mencari ulang. Tidak hanya itu, dengan menggunakan bookmark manager mahasiswa tidak kesulitan untuk membuat daftar pustaka karena alamat link yang digunakan sebagai rujukan maupun sumber referensi telah disimpan dalam bookmark manager. Hal ini dikarenakan untuk menyimpan alamat link hanya perlu mengklik saja tanpa proses yang panjang. Dari semua informasi yang tersimpan dalam bookmark manager ini kemungkinan akan digunakan pada saat itu juga maupun di kemudian hari. Selain

23 Kanwal Ameen, "Personal Information Management Practices and Behaviors of Social Sciences' Students," Pakistan Journal of Information Management and Libraries 18, no. 1 (2016): $12-24$. 
itu informasi yang tersimpan merupakan informasi akan digunakan untuk memenuhi kebutuhan informasi.

\section{Evaluasi Manajemen Informasi Pribadi dan Perilaku Mahasiswa dalam Memanfaatkan Bookmark Manager}

Kegiatan yang dilakukan sebelum adanya evaluasi yaitu menyimpan dan mengelola informasi dengan menggunakan media penyimpanan bookmark manager. Evaluasi penting dilaksanakan, karena evaluasi merupakan proses identifikasi untuk mengukur sebuah kegiatan telah dilaksanakan sesuai dengan tujuan. Hasil dari evaluasi dapat dijadikan sebagai bahan acuan dalam melaksanakan kegiatan selanjutnya. Salah satu kegiatan yang dilakukan dalam evaluasi yaitu menyortir dan menghapus informasi yang tersimpan dalam bookmark manager. Evaluasi dilakukan ketika mahasiswa memiliki waktu yang cukup luang untuk menghapus informasi yang telah tersimpan. Sedangkan pada penelitian sebelumnya yang dilakukan oleh Alon dan Narchmias, ${ }^{24}$ proses evaluasi ini menjadi proses yang banyak dilakukan oleh penggunanya. Pada penelitian ini ditemukan kesenjangan yang sangat besar dalam perilaku mengatur dan perilaku menghapus, disampaikan bahwa peserta ingin menjadi lebih efisien dalam perilaku PIM mereka dan ingin mendedikasikan lebih banyak waktu untuk proses ini.

Penyortiran informasi ini dilakukan untuk memisahkan informasi yang akan digunakan kembali dengan informasi yang sudah tidak terpakai. Berdasarkan pendapat mahasiswa diketahui bahwa dengan melakukan evaluasi yang dilakukan oleh Alon dan Narchmias dalam bentuk penyortiran informasi memudahkan mereka dalam mencari kembali informasinya. Sebagian mahasiswa melakukan evaluasi namun kegiatan ini jarang untuk dilakukan, karena bagi mereka untuk melakukan penyortiran membutuhkan waktu yang spesifik untuk menghapus informasi yang sudah tidak relevan. Selain itu dijumpai pula mahasiswa yang tidak pernah melakukan evaluasi pada informasi yang dimilikinya. Semakin

\footnotetext{
24 Alon and Nachmias, "Gaps between Actual and Ideal Personal Information Management Behavior."
} 


\section{Mutia Larasati, Yanuar Yoga Prasetyawan, Personal Information ...}

banyak informasi yang tersimpan dalam bookmark manager akan menjadi masalah tersendiri bagi mahasiswa. Tujuan awal menggunakan bookmark manager yaitu agar cepat dalam temu balik informasi, namun jika informasi yang disimpan semakin banyak dan tidak dilakukan pemilahan maka informasi tersebut akan menumpuk. Penggunaan bookmark manager diperuntukkan untuk membantu seseorang dalam menyimpan informasi yang dimilikinya. Dengan berbagai fasilitas yang diberikan serta kemudahan yang ada, maka perlu dilihat pula permasalahan selama menggunakan bookmark manager.

Permasalahan yang dijumpai mahasiswa selama menggunakan bookmark manager bukan berasal dari media penyimpanananya melainkan berasal dari diri mahasiswa. Mahasiswa terkadang kebingungan untuk mengingat kembali dimana informasinya disimpan dalam bookmark manager. Namun bagi mereka yang menggunakan folder dalam menyimpan dan mengelola informasi tidak menemukan masalah yang cukup berarti. Selain itu, mahasiswa terkadang lupa untuk menyimpan informasi yang telah ditemukan setelah menghapus histori hasil penelusuran. Selama menggunakan bookmark manager setiap mahasiswa memiliki pendapatnya masing masing, selain kelebihan atau manfaat yang didapatkan ditemui juga kekurangannya. Kekurangan yang dijumpai mahasiswa yaitu fasilitas yang diberikan kurang lengkap, seperti halnya tampilan yang masih mengikuti tampilan standar dari google (default), tidak ada search engine untuk menemukan kembali informasi yang tersimpan, dan tidak disertai waktu penyimpanan yang berupa tanggal dan jam.

\section{PENUTUP}

Hasil penelitian ini menunjukan bahwa manajemen informasi pribadi dan perilaku mahasiswa Undip dapat diketahui ketika mahasiswa melakukan pengorganisasian terhadap informasi yang dimilikinya dengan menggunakan boomark manager. Diketahui bahwa tujuan dari penelitian ini yaitu untuk mengidentifikasi bagaimana manajemen informasi pribadi dan perilaku mahasiswa Undip dalam memanfaatkan bookmark manager. Manajemen informasi pribadi dan perilaku mahasiswa antara satu dengan yang lain berbeda. 
Terdapat banyak faktor yang mempengaruhi bagaimana mahasiswa dalam melakukan manajemen informasi pribadi. Kaitannya dengan hal tersebut, hasil penelitian menunjukkan bahwa kegiatan manajemen informasi pribadi yang dilakukan mahasiswa yaitu 1) penyeleksian informasi 2) penyimpanan informasi 3) pengelolaan informasi, dan 4) evaluasi.

\section{DAFTAR RUJUKAN}

Abdus Sattar Chaudhry, Sajjad ur Rehman, and Lulwah Al-Sughair, "Personal Information Management Practices in the Kuwaiti Corporate Sector," Malaysian Journal of Library and Information Science 20, no. 3 (2015): 2742.

Barbara and Peter J. Thomas Etzel, Personal Information Management: Tools and Techniques for Achieving Professional Effectiveness (Publication Data, 1996).

Dan Balanescu, "The Youth of Today - The Generation of the Global Development - Special Section for Students and MA Students A Lead Provided by Bookmarks - Intelligent Browsers," 2015, 720-26.

David Elsweiler, Mark Baillie, and Ian Ruthven, "What Makes Re-Finding Information Difficult? A Study of Email Re-Finding," in Lecture Notes in Computer Science (Including Subseries Lecture Notes in Artificial Intelligence and Lecture Notes in Bioinformatics), vol. 6611 LNCS (Berlin, Germany: Spring-Verlag, 2011), 568-79, https://doi.org/10.1007/978-3-64220161-5_57.

Djam'an Satori and Aan Komariah, Metodologi Penelitian Kualitatif (Bandung: Alfabeta, 2012).

Donghee Sinn, Sujin Kim, and Sue Yeon Syn, "Information Activities within Information Horizons: A Case for College Students' Personal Information Management," Library and Information Science Research 41, no. 1 (2019): 19-30, https://doi.org/10.1016/j.lisr.2019.02.003.

Haris Herdiansyah, Metode Penelitian Kualitatif Untuk Ilmu-Ilmu Sosial (Jakarta: Salemba Humanika, 2012).

Kanwal Ameen, "Personal Information Management Practices and Behaviors of Social Sciences' Students," Pakistan Journal of Information Management and Libraries 18, no. 1 (2016): 12-24.

Lala Hajibayova, "Exploring Individuals' Patterns of Personal Information Management Practices: Factors Influencing the Representation, Organization 
Mutia Larasati, Yanuar Yoga Prasetyawan, Personal Information ...

and Credibility Assessment of Information," Information Research 24, no. 3 (2019).

Lexy J Moleong, Metodologi Penelitian Kualitatif (Jakarta: Remaja Rosdakarya Offset, 2007).

Lilach Alon and Rafi Nachmias, "Gaps between Actual and Ideal Personal Information Management Behavior," Computers in Human Behavior 107, no. February (2020): 106292, https://doi.org/10.1016/j.chb.2020.106292.

Ofer Bergman and Steve Whittaker, "The Science of Managing Our Digital Stuff," MIT Pres, 2016, https://doi.org/10.17723/0360-9081-81.1.233 .

Siu Tsen Shen, "Exploring the Effects of Multidimensional Context on Human Performance in Personal Bookmark Management," Mathematical Problems in Engineering 2013 (2013), https://doi.org/10.1155/2013/932586.

Steve Whittaker et al., "Am I Wasting My Time Organizing Email? A Study of Email Refinding," Conference on Human Factors in Computing Systems Proceedings, 2011, 3449-58, https://doi.org/10.1145/1978942.1979457.

Sugiyono, Metode Penelitian Kuantitatif, Kualitatif Dan R\&D (Bandung: PT Alfabet, 2016).

Thomas W. Malone, "How Do People Organize Their Desks?: Implications for the Design of Office Information Systems," ACM Transactions on Information Systems (TOIS) 1, no. 1 (1983): 99-112, https://doi.org/10.1145/357423.357430.

William Jones, "Personal Information Management," Annual Review of Informartion Science \& Technology 41, no. 1 (2007): 453-504, https://doi.org/10.1002/aris.2007.1440410117.

William Jones, Keeping Found Things Found: The Study of Practice Personal Information Management (Morgan Kaufmann Publishers, 2008). 